\title{
Clinical Considerations of Coagulopathy in Acute Liver Failure
}

\author{
Ahyoung $\mathrm{Kim}^{1}$, Bolin $\mathrm{Niu}^{2}$, Tinsay Woreta ${ }^{1}$ and Po-Hung Chen* ${ }^{1}$ \\ ${ }^{1}$ Division of Gastroenterology \& Hepatology, Department of Medicine, Johns Hopkins University School of Medicine, Baltimore, \\ MD, USA; ${ }^{2}$ Division of Gastroenterology \& Hepatology, Department of Medicine, Case Western Reserve University School of \\ Medicine, Cleveland, $\mathrm{OH}$, USA
}

\begin{abstract}
Acute liver failure (ALF) is the rapid onset of severe liver dysfunction, defined by the presence of hepatic encephalopathy and impaired synthetic function (international normalized ratio of $\geq 1.5$ ) in the absence of underlying liver disease. The elevated international normalized ratio value in ALF is often misinterpreted as an increased hemorrhagic tendency, which can lead to inappropriate, prophylactic transfusions of blood products. However, global assessments of coagulopathy via viscoelastic tests or thrombin generation assay suggest a reestablished hemostatic, or even hypercoagulable, status in patients with ALF. Although the current versions of global assays are not perfect, they can provide more nuanced insights into the hemostatic system in ALF than the conventional measures of coagulopathy.
\end{abstract}

Citation of this article: Kim A, Niu B, Woreta T, Chen PH. Clinical considerations of coagulopathy in acute liver failure. J Clin Transl Hepatol 2020;8(4):407-413. doi: 10.14218/ JCTH.2020.00058.

\section{Introduction}

Acute liver failure (ALF) is a rare, rapidly progressive syndrome that results from an acute onset of severe liver dysfunction. The most commonly accepted definition of ALF includes the development of hepatic encephalopathy and coagulopathy (international normalized ratio [INR] of 21.5). ${ }^{1,2}$ The onset of acute symptoms occurs within 26 weeks, according to the American Association for the Study of Liver Diseases (AASLD). ${ }^{1}$ But different societies have slightly different variations on the temporal classifications; for example, the European Association for the Study of the

Keywords: Acute liver failure; Coagulopathy; Thrombin generation assay; Viscoelastic test.

Abbreviations: AASLD, American Association for the Study of Liver Diseases; ALF, acute liver failure; ALI, acute liver injury; APASL, Asian Pacific Association for the Study of the Liver; aPTT, activated partial thromboplastin time; EASL, European Association for the Study of the Liver; HE, hepatic encephalopathy; IASL, International Association for the Study of the Liver; ICP, intracranial pressure; INR, International Normalized Ratio; MELD, Model for End-Stage Liver Disease; PAI-1, plasminogen activator inhibitor-1; PT, prothrombin time; ROTEM, rotational thromboelastometry; TAFI, thrombin activatable fibrinolysis inhibitor; TEG, thromboelastography; TFPI, tissue factor pathway inhibitor; TGA, thrombin generation assay; tPA, tissue plasminogen activator; TPO, thrombopoietin; VET, viscoelastic test; vWF, von Willebrand factor.

Received: 20 June 2020; Revised: 8 August 2020; Accepted: 31 August 2020

*Correspondence to: Po-Hung Chen, Division of Gastroenterology \& Hepatology, Department of Medicine, Johns Hopkins University School of Medicine, 1830 E. Monument Street, Suite 429, Baltimore, MD 21287, USA. Tel: +1-410-6143530, Fax: +1-410-550-7861, E-mail: pchen37@jhmi.edu
Liver (EASL) suggests three separate temporal subclassifications, ${ }^{2}$ while the International Association for the Study of the Liver (IASL) and the Asian Pacific Association for the Study of the Liver (APASL) both employ a timeline of 4 weeks (Table 1). ${ }^{3-5}$ Unless otherwise specified, the present review will focus on the AASLD definition of ALF. INR reflects the disruptions in hepatic synthetic function in ALF and is an essential and useful clinical prognosticating tool. Clinicians often rely on INR to assess bleeding risk in ALF. ${ }^{6}$ However, recent studies have demonstrated that a careful approach is indispensable when interpreting raw INR values in the context of hemostasis and bleeding diathesis in ALF. In this review, we present the utility of INR as a reflection of coagulopathy, the arguments for reestablished hemostatic system in ALF, and the suggested tools for evaluating coagulopathy in ALF.

\section{Interpretation of the INR value}

Several reasons preclude the use of INR as the measure of coagulopathy in ALF. First, INR was designed for the specific indication of evaluating the interference of vitamin K-dependent clotting pathway, such as in warfarin-induced coagulopathy. ${ }^{7}$ INR is less relevant in ALF because both vitamin Kdependent and -independent factors contribute to the coagulopathy. Second, INR reflects only the changes in procoagulant factors. INR arises from prothrombin time (PT) and is calculated as a ratio of patient's PT to standardized PT. ${ }^{8}$ The laboratory measures of PT and activated partial thromboplastin time (aPTT) capture only the reduction in procoagulant factors. ${ }^{9}$ These conventional studies of "coagulation" do not reflect any deficiencies in anticoagulant factors such as protein $\mathrm{C}$, protein $\mathrm{S}$, antithrombin, and tissue factor pathway inhibitor (commonly referred to as TFPI) that are also substantially reduced in ALF. ${ }^{10}$ Dynamic interactions between all these cellular components do not fully enter the INR. ${ }^{11}$ Lastly, INR is unreliable. There can be large interlaboratory discrepancies between INR measurements in patients with liver disease because this test was not developed to reflect coagulopathy in liver disease. ${ }^{12}$ Robert and Chazoulleres ${ }^{12}$ demonstrated that INR provided inadequate normalization of PT in patients with liver failure, whereas INR normalized PT in anticoagulated patients. Trotter et al. ${ }^{13}$ additionally showed a significant inconsistency in INR results by sending a sample of blood to three reference laboratories. The laboratory variability resulted in different Model for End-Stage Liver Disease (commonly known as MELD) scores and an average change in organ allocation priority from $58^{\text {th }}$ to $77^{\text {th }}$ percentile $(p=0.01)$. The irregularities in PT/INR were thought to be due to different sample storage time, 
Kim A. et al: Coagulopathy in acute liver failure

Table 1. Definitions of ALF

\begin{tabular}{|c|c|c|c|}
\hline Society & ALF definition & Time course & Notes \\
\hline AASLD & $\begin{array}{l}\text { Presence of INR } \geq 1.5 \text { and any degree } \\
\text { of } \mathrm{HE}\end{array}$ & $\begin{array}{l}\text { Illness duration of }<26 \\
\text { weeks }\end{array}$ & $\begin{array}{l}\text { - Without preexisting cirrhosis except } \\
\text { for patients with Wilson's disease, } \\
\text { vertically-acquired hepatitis B virus, or } \\
\text { autoimmune hepatitis } \\
\text { - AASLD does not formally endorse } \\
\text { ALF subgroups based on time course }\end{array}$ \\
\hline EASL & $\begin{array}{l}\text { Presence of acute abnormality of liver } \\
\text { blood tests associated with } \\
\text { coagulopathy (INR of }>1.5 \text { ) of liver } \\
\text { etiology and } \mathrm{HE} / \text { jaundice }\end{array}$ & $\begin{array}{l}\text { - Hyperacute: } \\
\text { development of HE within } 7 \\
\text { days of jaundice } \\
\text { - Acute: development of } \\
\text { HE between } 8 \text { and } 28 \text { days } \\
\text { of jaundice } \\
\text { - Subacute: development } \\
\text { of HE within 5-12 weeks of } \\
\text { jaundice }\end{array}$ & $\begin{array}{l}\text { - Without previous severe fibrotic or } \\
\text { cirrhotic chronic liver disease, except } \\
\text { for patients with acute de novo } \\
\text { autoimmune hepatitis, Budd-Chiari } \\
\text { syndrome and Wilson's disease } \\
\text { - Jaundice is considered the first } \\
\text { symptom }\end{array}$ \\
\hline IASL & $\begin{array}{l}\text { Presence of sudden and progressive } \\
\text { liver dysfunction characterized by } \mathrm{HE}\end{array}$ & $\begin{array}{l}\text { Development of HE within } \\
4 \text { weeks of onset of } \\
\text { symptoms } \\
\text { - Hyperacute: }<10 \text { days } \\
\text { - Fulminant: } 10-30 \text { days }\end{array}$ & $\begin{array}{l}\text { - Without preexisting liver disease, } \\
\text { except for patients with Wilson's } \\
\text { disease and drug/toxic or viral } \\
\text { hepatitis superimposed on preexisting } \\
\text { liver disease }\end{array}$ \\
\hline APASL & $\begin{array}{l}\text { Presence of severe liver injury, } \\
\text { coagulopathy INR of } \geq 1.5 \text {, and any } \\
\text { degree of } \mathrm{HE}\end{array}$ & $\begin{array}{l}\text { Illness duration up to } 4 \\
\text { weeks }\end{array}$ & $\begin{array}{l}\text { - Without chronic liver disease or } \\
\text { cirrhosis }\end{array}$ \\
\hline $\begin{array}{l}\text { Acute Liver } \\
\text { Failure } \\
\text { Study } \\
\text { Group of } \\
\text { Japan }\end{array}$ & $\begin{array}{l}\text { Presence of fulminant hepatitis with } \\
\mathrm{HE} \text { and PT time less than } 40 \% \text { of } \\
\text { standardized value }\end{array}$ & $\begin{array}{l}\text { Development of grade II or } \\
\text { more severe HE within } 8 \\
\text { weeks of onset of disease } \\
\text { symptoms } \\
\text { - Acute: HE within } 10 \text { days } \\
\text { - Subacute: HE later than } \\
11 \text { days }\end{array}$ & $\begin{array}{l}\text { - Exclude acute liver failure caused by } \\
\text { drug/chemical intoxication and } \\
\text { microcirculatory disturbances, } \\
\text { Wilson's disease, acute fatty liver of } \\
\text { pregnancy and Reye's syndrome } \\
\text { - Include asymptomatic hepatitis B } \\
\text { virus carriers showing acute } \\
\text { exacerbation of hepatitis }\end{array}$ \\
\hline
\end{tabular}

Abbreviations: ALF, acute liver failure; AASLD, American Association for the Study of Liver Diseases; INR, international normalized ratio; HE, hepatic encephalopathy; EASL, European Association for the Study of the Liver; IASL, International Association for the Study of the Liver; APASL, Asian Pacific Association for the Study of the Liver; PT, prothrombin time.

international sensitivity index of the thromboplastin, instrumentation, and the methodology used. ${ }^{10}$

The differences in PT/INR values within subclasses of ALF yield an interesting observation. In a study of 131 patients at the King's College in England, PT was more prolonged in fulminant hepatic failure (development of hepatic encephalopathy [HE] within 8 weeks) at median of 58 seconds when compared to PT in late-onset hepatic failure (development of $\mathrm{HE}$ between 8 and 24 weeks) at median of 32 seconds $(p<0.01) .{ }^{14}$ Similarly, the landmark Lancet study that first described the temporal subclassifications of ALF adopted by the EASL guidelines showed that the admission PT value was highest in the ALF group (development of HE within 8-28 days of jaundice), followed by the hyperacute liver failure group (development of HE within 0-7 days of jaundice) and the subacute liver failure group (development of HE within 29-72 days of jaundice). ${ }^{15}$ Despite this interesting observation, the clinical significance in terms of coagulopathy and bleeding risk behind these differences in PT/INR values in ALF subgroups has not been explored.

Elevated INR is frequently observed in ALF but bleeding complications are uncommon. Munoz et al. ${ }^{7}$ studied more than 1,000 patients with ALF from the Acute Liver Failure
Study Group, a consortium of 24 tertiary care liver centers collecting data on patients with ALF. The mean INR of this cohort was 3.8 (ranging from 1.5 to $>10.0$ ). At admission, $81 \%$ of their cohort had an INR value between 1.5 and 5.0 . Fourteen percent had an INR value ranging from 5.0 to 10.0 , and $5 \%$ had an INR $>10.0 .^{7}$ Another study on 2,095 ALF patients who presented to the Liver Intensive Therapy Unit at Kings College Hospital between 1973 and 2008 showed a similar INR profile. The mean INR in their cohort of 840 nonparacetamol ALF patients was 3.5 (range of 2.3 to 6 ), and the mean INR in their cohort of 1,255 paracetamol ALF patients was 6.2 (range of 3.9 to 9.3). ${ }^{16}$ Despite the elevated INR values, spontaneous overt bleeding in ALF has been reported to be uncommon. ${ }^{17-20}$ Bleeding in ALF is usually silent or manifested as mucosal membrane bleeding, often gastrointestinal in origin. $7,19,21$ In the ALF Study Group, the INR values of ALF patients who experienced bleeding were not significantly different from those who did not experience bleeding. ${ }^{7}$ Bleeding complications from invasive procedures such as the placement of an intracranial pressure (ICP) monitor is also comparable to those without invasive procedures. In a cohort of 58 ALF patients, bleeding from ICP monitor placement was $10.3 \%$, and half of the complications 
were incidental radiological findings. ${ }^{22}$ More recently published in 2018, the overall incidence of bleeding was $10.6 \%$ during the first 7 days of admission, $89 \%$ spontaneous and $11 \%$ post-procedural, in a cohort of 1,770 adult patients with ALF in the ALF Study Group Registry. Bleeding complications were the cause of death in $2.1 \%$ of their patients. Importantly, INR was not statistically different between bleeders and non-bleeders. ${ }^{6}$

\section{Rebalanced hemostasis in ALF}

The exact mechanism of coagulopathy in ALF remains to be fully elucidated. However, current evidence suggests that the coagulopathy in ALF is derived from a complex and delicate interplay between decreased synthesis of procoagulant factors and anticoagulant factors, impaired fibrinolytic systems, defective platelets, and thrombocytopenia. ${ }^{7,17,23} \mathrm{~A}$ significant alteration to the hemostatic system between procoagulant and anticoagulant pathways in ALF results in a delicate balance. ${ }^{24}$ Any insult to this newly established system can tip the scale toward either thrombotic or bleeding complications. ${ }^{19}$

Acute hepatocellular injury leads to a considerable reduction in coagulation factor levels, as reflected by the prolonged PT/INR values. Hepatocytes synthesize most coagulation factors, including fibrinogen and factors II (prothrombin), V, VII, IX, X, XI, and XII. ${ }^{25}$ In the 1970s, Boks et $a .^{26}$ reported that the levels of clotting factors were extremely depressed in their cohort of 7 ALF patients. In another study, 31 patients with acute paracetamol overdose showed reduced coagulation factors II, V, VII, and X but increased levels of factor VIII, an acute phase reactant synthesized in endothelial cells. ${ }^{19,25,27,28}$ Coagulation factors also have a short half-life, ${ }^{23}$ which augments the effect of reduced production of coagulation factors in ALF. These changes in coagulant factors are offset by decreased anticoagulant proteins in $\mathrm{ALF}^{19}$ Anticoagulant proteins, such as protein $C$, protein S, protein Z, protein Z-dependent protease inhibitor, antithrombin, heparin cofactor II, and $\alpha 2$-macroglobulin, are all synthesized by the liver; ${ }^{10,29,30}$ an acute injury to hepatocytes leads to a diminished generation of these factors.

In addition to the decreased levels of coagulant and anticoagulant factors, fibrinogen is affected qualitatively and quantitatively in ALF. Fibrinogen is a glycoprotein that is cleaved by thrombin into fibrin to form a blood clot. ${ }^{31}$ Green et $a .^{32}$ first reported the primary abnormality in fibrinogen in ALF by demonstrating varying degrees of disturbances in fibrin polymerization. A follow-up study modified the original calorimetry technique by Green et al. and reported dysfibrinogenemia in $86 \%$ of their 29 ALF patients. ${ }^{33}$ These two studies confirmed the high incidence of acquired dysfibrinogenemia in ALF. Furthermore, fibrinogen produced in patients with ALF has increased amounts of sialic acid, which results in abnormal fibrinogen function and prolonged thrombin time. ${ }^{25}$ Quantitatively, fibrinogen levels are typically normal or slightly reduced in $\mathrm{ALF}^{10,25}$ likely related to the fact that fibrinogen is an acute-phase protein. ${ }^{19}$ Qualitatively, the disturbance in fibrinogen may contribute to coagulopathy in ALF.

Fibrinolysis, a process that prevents clotting, is also affected in ALF. All proteins involved in fibrinolysis, except for tissue plasminogen activator (tPA) and plasminogen activator inhibitor-1 (PAI-1), are synthesized by the liver. ${ }^{24}$ The plasma levels of plasminogen, antiplasmin ( $\alpha-2$ plasmin inhibitor or $\alpha-2 \mathrm{PI}$ ), thrombin activatable fibrinolysis inhibitor (TAFI), and factor XIII are all significantly reduced in ALF. ${ }^{10,24,26}$ The plasma levels of tPA and PAI-1 (inhibitor of tPA) are increased during ALF, due to their release by activated endothelium and reduced hepatic clearance. ${ }^{10,19,25}$ However, PAI-1 levels are even more substantially increased than tPA levels in ALF, resulting in impaired fibrinolysis and hypofibrinolysis in ALF. ${ }^{10,19,24}$

Platelet dysfunction is routinely observed in ALF. ${ }^{23}$ In addition, there may be mild to moderate reduction in platelet count, ${ }^{17,19,24}$ though some patients may still retain normal platelet counts. According to data of more than 1,000 ALF patients from the Acute Liver Failure Study Group, the median platelet level was $132,000 / \mathrm{mL}$ (range of 1,000 to 533,000$)^{7}$. Thrombocytopenia in ALF is thought to result from impaired platelet production and thrombin-mediated platelet consumption, though the exact mechanism is not yet known. ${ }^{23}$ Initially, it was hypothesized that the decreased synthesis of thrombopoietin (TPO) was responsible for thrombocytopenia in ALF because TPO is produced by the liver. However, Schiødt et al. ${ }^{34}$ measured the TPO level in 51 patients with ALF and reported that TPO level was above the upper limit of normal in 22 patients, normal in 24 patients, and below normal in only 5 patients. TPO levels did not correlate with platelet count in ALF. However, the level and function of platelet adhesive protein von Willebrand factor ( $V W F)$ and its cleaving protease ADAMTS13 in plasma have shown to affect platelet function in acute liver injury (ALI) and ALF. ALI is defined as INR of $\geq 1.5$ in the absence of prior liver disease and illness duration of $\leq 26$ weeks but without hepatic encephalopathy. vWF is a multimeric protein that is essential to platelet adhesion, and its reactivity towards platelets is proportional to its size, which is regulated by ADAMTS13. When compared to control subjects, patients with ALI and ALF had highly elevated vWF levels but reduced VWF function and reduced ADAMTS13 level and function. The overall platelet activity was normal or perhaps even increased; the rise in the concentration of VWF and decreased ADAMTS13 level and function more than compensated for the decrease in vWF function. ${ }^{11,35}$

There is also evidence suggesting that ALF may be a hypercoagulable state. Stravitz et al. ${ }^{36}$ conducted a study on $50 \mathrm{ALI} / \mathrm{ALF}$ patients assessing the level of microparticles in their plasma. Microparticles are procoagulant membrane fragments (ranging in size from 0.1 to $1.0 \mu \mathrm{m}$ ) derived from various cells. In their cohort, three dominant sizes of microparticles $(0.27,0.28$ to $0.64,>0.64 \mu \mathrm{m})$ were detected in ALI/ ALF patients and healthy controls, and the ALI/ALF patients had a significantly higher concentration of all sizes of microparticles. When displaying tissue factor, a membrane protein vital in initiating coagulation 37,38 these highly procoagulant microparticles released from acutely injured liver potentially mediate the activation of coagulation and result in intravascular coagulation. The process further exacerbates liver damage in ALF. ${ }^{36}$

Overall, there is an overwhelming amount of evidence to suggest that the hemostasis in ALF is complex and rebalanced (Table 2, Fig. 1). Reduction in procoagulant factors counters diminished anticoagulant factors. Decreased levels of antiplasmin and TAFI offset increased levels of PAI-1 and reduced plasminogen. The increased amount of vWF compensates for the platelet dysfunction. Microparticles may even 
Kim A. et al: Coagulopathy in acute liver failure

Table 2. Changes of hemostasis in ALF

\begin{tabular}{|c|c|c|}
\hline Factors & Factors contributing to anticoagulation & Factors contributing to coagulation \\
\hline Coagulation factors & - Reduced procoagulant factors & $\begin{array}{l}\text { - Reduced anticoagulant factors } \\
\text { - Increased factor VIII }\end{array}$ \\
\hline Fibrinolytic pathway & $\begin{array}{l}\text { - Increased tPA } \\
\text { - Reduced TAFI } \\
\text { - Reduced antiplasmin }\end{array}$ & $\begin{array}{l}\text { - Increased PAI-1 (more than tPA) } \\
\text { - Reduced plasminogen }\end{array}$ \\
\hline Fibrinogen & - Dysfibrinogenemia & N/A \\
\hline Platelets & $\begin{array}{l}\text { - Platelet dysfunction } \\
\text { - Thrombocytopenia }\end{array}$ & $\begin{array}{l}\text { - Increased vWF } \\
\text { - Reduced ADAMTS13 }\end{array}$ \\
\hline Microparticles & N/A & - Increased microparticles \\
\hline
\end{tabular}

Abbreviations: ALF, acute liver failure; N/A, not applicable; PAI-1, plasminogen activator inhibitor-1; TAFI, thrombin activatable fibrinolysis inhibitor; tPA, tissue plasminogen activator; vWF, von Willebrand factor.

play a role in normalizing coagulopathy. Hence, an elevated INR does not fully represent the cellular processes in ALF.

\section{Assessing hemostasis in ALF}

\section{Viscoelastic tests}

Conventional coagulation tests, such as PT/INR, do not entirely represent the in vivo process in the in vitro setting. Global assays that consider all aspects of coagulopathy, including pro/anticoagulation mechanisms and fibrinolysis, offer many advantages in ALF. More recently, viscoelastic tests (VET) of coagulopathy, including thromboelastographic (TEG) and rotational thromboelastometry (ROTEM), have emerged for non-surgical applications in acute and chronic liver diseases. VET is a single point-of-care assay that allows for real-time functional evaluation of viscoelastic properties of coagulation, including dynamics of clot formation, ultimate clot strength, clot stability, and degradation. ${ }^{11,39-42}$ TEG and ROTEM have long been utilized in liver transplantation as its use reduces blood and fluid infusion volume during surgery. ${ }^{43-45}$

In ALF, the parameters reflecting primary and secondary hemostasis are typically normal on TEG. Stravitz et al. ${ }^{11}$ conducted a prospective ancillary project to The Acute Liver Failure Study Group and performed TEG on 50 patients with ALI/ALF on admission. The mean INR was elevated at 3.4 (range of 1.5 to 9.6 ) but the mean and median TEG parameters were normal for the entire population. Thirtytwo patients $(63 \%)$ had normal TEG studies, and four patients $(8 \%)$ actually had hypercoagulable TEG parameters. Normal clot formation was observed without activation

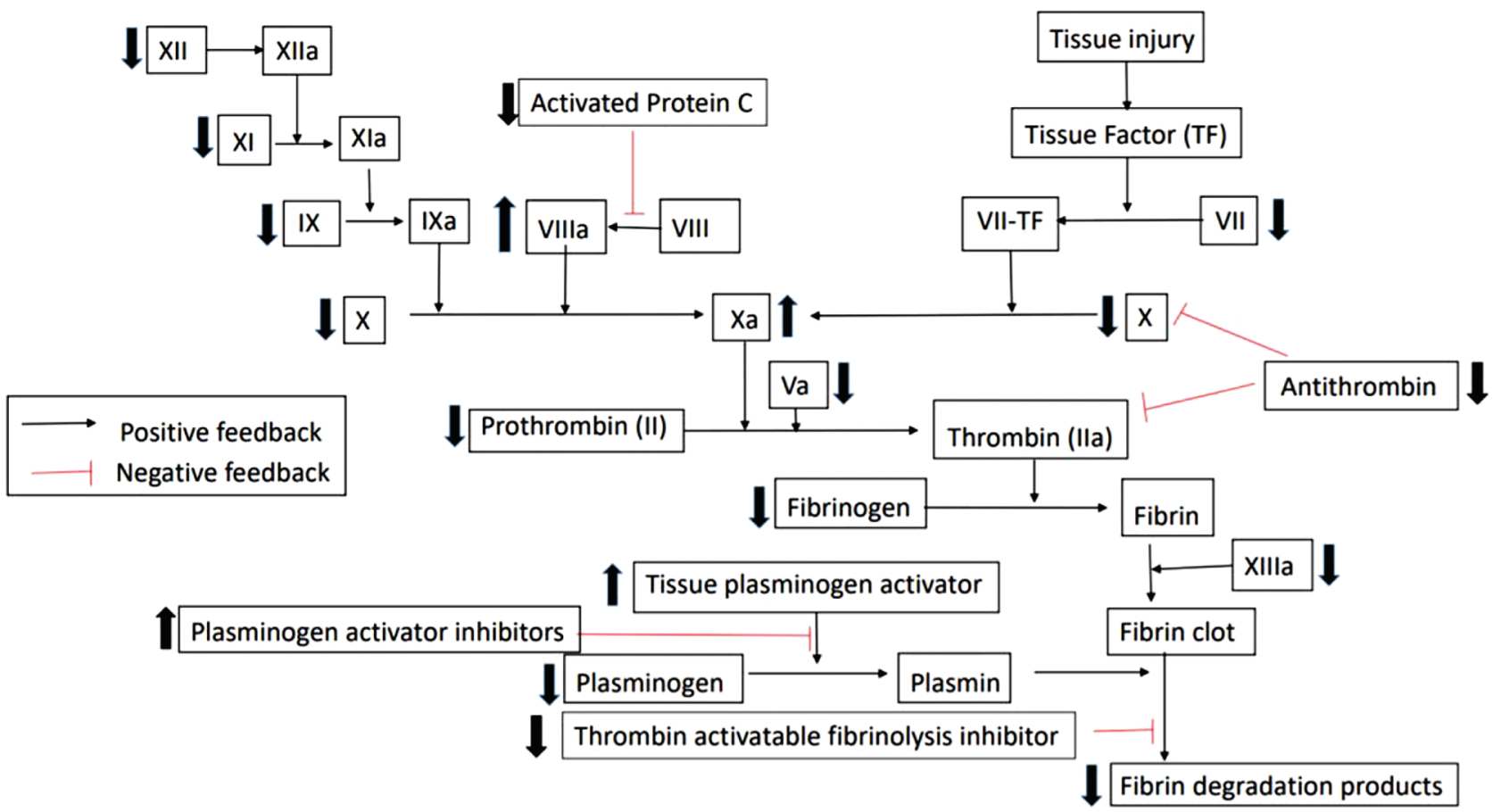

Fig. 1. Coagulation cascade in acute liver failure 
Kim A. et al: Coagulopathy in acute liver failure

Table 3. Different modalities of coagulopathy measurement in ALF

\begin{tabular}{|c|c|c|}
\hline & Pros & Cons \\
\hline $\begin{array}{l}\text { Conventional tests } \\
\text { (platelets/PT/INR) }\end{array}$ & $\begin{array}{l}\text { - Quick } \\
\text { - Widely available }\end{array}$ & $\begin{array}{l}\text { - Inability to measure platelet dysfunction } \\
\text { - Variability in PT/INR in liver disease } \\
\text { rendering inaccurate measurements }\end{array}$ \\
\hline VET & $\begin{array}{l}\text { - Quick } \\
\text { - Clinically available } \\
\text { - Widely used in trauma, liver transplantation, } \\
\text { cardiac surgeries to guide transfusions }\end{array}$ & $\begin{array}{l}\text { - Insensitive to vWF } \\
\text { - Lack of protein } \mathrm{C} \text { activation } \\
\text { - Absence of precise molecular mechanism } \\
\text { behind tracings }\end{array}$ \\
\hline TGA & $\begin{array}{l}\text { - Ability to study precise molecular mechanisms } \\
\text { - More global assessment of coagulopathy including } \\
\text { protein C activation and vWF }\end{array}$ & $\begin{array}{l}\text { - Time consuming } \\
\text { - Only available in research setting }\end{array}$ \\
\hline
\end{tabular}

Abbreviations: INR, international normalized ratio; PT, prothrombin time; TGA, thrombin generation assay; VET, viscoelastic tests; vWF, von Willebrand factor; TGA, thrombin generation assay.

of the protein $\mathrm{C}$ system. ${ }^{11}$ Furthermore, the authors reported that the number of thrombotic complications was higher than bleeding complications. Bleeding was reported in six patients, while thrombosis occurred in eleven patients. ${ }^{11}$ In another study, plasma samples from 20 ALF patients showed similar results. The median INR in their cohort was 4.1 (interquartile range from 2.2 to 6.1 ) but it did not correlate with the TEG parameters. The authors demonstrated hypocoagulable TEG tracing in $20 \%$, normal TEG tracing in $45 \%$, and hypercoagulable tracing in $35 \% .{ }^{46}$ No significant bleeding complications or need for blood transfusions occurred in their study. ${ }^{46}$ In summary, TEG tracings suggest perhaps a reestablished hemostasis system in ALF despite the elevated INR values.

\section{Thrombin generation assay}

VET is a useful bedside tool, where the results are typically available within minutes and the tracings available in realtime. However, one critique is that VET may not represent the true hemostatic balance in ALF because it lacks protein $C$ activation and is insensitive to VWF in cirrhotic patients. ${ }^{47}$ Thrombin generation assay (TGA) overcomes the inherent weaknesses of VET by providing a more accurate interplay between pro- and anticoagulant factors in ALF, thus evaluating the coagulopathy globally. However, unlike VET, TGA can be time-consuming and is currently only available in research settings. 48

Lisman et al. ${ }^{49}$ performed TGA using the Calibrated Automated Thrombogram on 50 patients with ALI/ALF and 40 healthy controls. Thrombin generation in patients with ALI/ALF was not significantly different from thrombin generation in control subjects when thrombomodulin was added to test mixture. ${ }^{49}$ The presence of thrombomodulin allowed for full activation of protein $\mathrm{C}$ in ALF, a condition known to have protein $C$ deficiency. ${ }^{9}$ This finding of indistinguishable thrombin generation between ALI/ALF patients and control subjects supports the state of reestablished hemostasis in ALF. Fibrinolytic capacity was also significantly impaired in ALI/ALF patients, supporting hypofibrinolysis in these patients. No lysis was observed within $3 \mathrm{~h}$ in $73.5 \%$ of ALI/ALF patients but in only $2.5 \%$ of healthy controls. This phenomenon was associated with decreased levels of plasminogen and increased levels of PAI-1. ${ }^{49}$ Moreover, the intact thrombin-generating capacity and hypofibrinolytic status persisted throughout the first week of admission in ALI/ALF patients. ${ }^{49}$ Habib et al. ${ }^{50}$ conducted a similar study on 32 patients with ALI/ALF and 40 control subjects utilizing TGA. Patients with ALI/ALF had a median INR of 3.36 (interquartile range 2.67 to 7.01 ) and decreased coagulation factors, except for factor VIII, as expected. The authors confirmed that thrombin generation in the presence of thrombomodulin in ALI/ALF patients was not significantly different from healthy controls. The ratio of thrombin generation with thrombomodulin to thrombin generation without thrombomodulin was significantly elevated in patients with ALI/ALF, suggesting hypercoagulable state in these patients. ${ }^{50}$ Again, study data showed that TGA demonstrates a rebalanced hemostatic system in ALF that is not reflected in elevated INR values.

\section{Conclusions}

Based on the current evidence, global assessment of hemostasis in ALF indicates a "rebalanced" state. Therefore, prophylactic transfusion of blood products is unwarranted and may expose patients to harmful effects, such as volume overload and transfusion reaction, without a clear benefit. ${ }^{17,23,47}$ Global tests of hemostasis have gained more recognition as potential tools in the evaluation of coagulopathy in patients with liver disease (Table 3). American Gastroenterological Association acknowledges the potential role of global assessment when evaluating clotting in patients with cirrhosis. ${ }^{51}$ Both the European Association for the Study of the Liver and the Society of Critical Care Medicine also recommend the use of thromboviscous technology, such as VET and TGA, to assess bleeding/thrombotic risks in critically ill patients with ALF. ${ }^{2,42}$ Neither the latest study data nor the most professional society guidelines support relying on INR as the sole measure of coagulopathy in ALF. Future iterations and standardization of VET and TGA are likely to provide a more comprehensive representation of coagulopathy in ALF.

\section{Funding}

This work was supported by the National Institute on Alcohol Abuse and Alcoholism of the National Institutes of Health under award number K23AA028297 (to PHC) and Johns Hopkins University Clinician Scientist Award (to PHC). The content is solely the responsibility of the authors and does not 
necessarily represent the official views of the National Institutes of Health.

\section{Conflict of interest}

The authors have no conflict of interests related to this publication.

\section{Author contributions}

Conceptualization and writing the original draft preparation (AK and $\mathrm{PHC}$ ), data curation and visualization (AK), funding acquisition and supervision (PHC), writing, review and editing (AK, BN, TW, and PHC).

\section{References}

[1] Lee WM, Stravitz RT, Larson AM. Introduction to the revised American Association for the Study of Liver Diseases Position Paper on acute liver failure 2011. Hepatology 2012;55:965-967. doi: 10.1002/hep.25551.

[2] Cordoba J, Dhawan A, Larsen FS, Manns M, Samuel D, Simpson KJ, et al. EASL Clinical Practical Guidelines on the management of acute (fulminant) liver failure. J Hepatol 2017;66:1047-1081. doi: 10.1016/j.jhep.2016.12. 003.

[3] Tandon BN, Bernauau J, O'Grady J, Gupta SD, Krisch RE, Liaw YF, et al. Recommendations of the International Association for the Study of the Liver Subcommittee on nomenclature of acute and subacute liver failure. J Gastroenterol Hepatol 1999;14:403-404. doi: 10.1046/j.1440-1746.1999. 01905.x.

[4] Mochida S, Nakayama N, Matsui A, Nagoshi S, Fujiwara K. Re-evaluation of the Guideline published by the Acute Liver Failure Study Group of Japan in 1996 to determine the indications of liver transplantation in patients with fulminant hepatitis. Hepatol Res 2008;38:970-979. doi: 10.1111/j.1872034X.2008.00368.X.

[5] Sarin SK, Choudhury A, Sharma MK, Maiwall R, Al Mahtab M, Rahman S, et al Acute-on-chronic liver failure: consensus recommendations of the Asian Pacific association for the study of the liver (APASL): an update. Hepatol Int 2019;13:353-390. doi: 10.1007/s12072-019-09946-3.

[6] Stravitz RT, Ellerbe C, Durkalski V, Schilsky M, Fontana RJ, Peterseim C, et al. Bleeding complications in acute liver failure. Hepatology 2018;67:19311942. doi: 10.1002/hep.29694.

[7] Munoz SJ, Rajender Reddy K, Lee W. The coagulopathy of acute liver failure and implications for intracranial pressure monitoring. Neurocrit Care 2008;9: 103-107. doi: 10.1007/s12028-008-9087-6.

[8] Riley RS, Rowe D, Fisher LM. Clinical utilization of the international normalized ratio (INR). J Clin Lab Anal 2000;14:101-114. doi: 10.1002/(SICI) 1098-2825(2000)14:3<101::AID-JCLA4>3.0.CO;2-A.

[9] Tripodi A, Salerno F, Chantarangkul V, Clerici M, Cazzaniga M, Primignani M, et al. Evidence of normal thrombin generation in cirrhosis despite abnormal conventional coagulation tests. Hepatology 2005;41:553-558. doi: 10. 1002/hep.20569.

[10] Caldwell SH, Hoffman M, Lisman T, Macik BG, Northup PG, Reddy KR, et al. Coagulation disorders and hemostasis in liver disease: pathophysiology and critical assessment of current management. Hepatology 2006;44:10391046. doi: 10.1002/hep. 21303.

[11] Stravitz RT, Lisman T, Luketic VA, Sterling RK, Puri P, Fuchs M, et al. Minimal effects of acute liver injury/acute liver failure on hemostasis as assessed by thromboelastography. J Hepatol 2012;56:129-136. doi: 10.1016/j.jhep. 2011.04.020.

[12] Robert A, Chazouillères O. Prothrombin time in liver failure: time, ratio, activity percentage, or international normalized ratio? Hepatology 1996; 24:1392-1394. doi: 10.1053/jhep.1996.v24.pm0008938167.

[13] Trotter JF, Brimhall B, Arjal R, Phillips C. Specific laboratory methodologies achieve higher model for endstage liver disease (MELD) scores for patients listed for liver transplantation. Liver Transpl 2004;10:995-1000. doi: 10. $1002 /$ It. 20195.

[14] Gimson AE, O'Grady J, Ede RJ, Portmann B, Williams R. Late onset hepatic failure: clinical, serological and histological features. Hepatology $1986 ; 6$ : 288-294. doi: 10.1002/hep.1840060222.

[15] O'Grady JG, Schalm SW, Williams R. Acute liver failure: redefining the syndromes. Lancet 1993;342:273-275. doi: 10.1016/0140-6736(93)91818-7.

[16] Bernal W, Hyyrylainen A, Gera A, Audimoolam VK, McPhail MJ, Auzinger G, et al. Lessons from look-back in acute liver failure? A single centre experi- ence of 3300 patients. J Hepatol 2013;59:74-80. doi: 10.1016/j.jhep. 2013.02.010.

[17] De Gasperi A, Corti A, Mazza E, Prosperi M, Amici O, Bettinelli L. Acute liver failure: managing coagulopathy and the bleeding diathesis. Transplant Proc 2009;41:1256-1259. doi: 10.1016/j.transproceed.2009.03.007.

[18] Bernal W, Wendon J. Acute liver failure. N Engl J Med 2013;369:2525-2534. doi: $10.1056 /$ NEJMra1208937.

[19] Lisman T, Stravitz RT. Rebalanced hemostasis in patients with acute liver failure. Semin Thromb Hemost 2015;41:468-473. doi: 10.1055/s-00351550430.

[20] Stravitz RT. Potential applications of thromboelastography in patients with acute and chronic liver disease. Gastroenterol Hepatol (N Y) 2012;8: 513-520.

[21] Shalimar, Acharya SK. Management in acute liver failure. J Clin Exp Hepatol 2015;5:S104-S115. doi: 10.1016/j.jceh.2014.11.005

[22] Vaquero J, Fontana RJ, Larson AM, Bass NM, Davern TJ, Shakil AO, et al. Complications and use of intracranial pressure monitoring in patients with acute liver failure and severe encephalopathy. Liver Transpl 2005;11:15811589. doi: $10.1002 / \mathrm{lt} .20625$

[23] Munoz SJ, Stravitz RT, Gabriel DA. Coagulopathy of acute liver failure. Clin Liver Dis 2009;13:95-107. doi: 10.1016/j.cld.2008.10.001.

[24] Lisman T, Leebeek FW. Hemostatic alterations in liver disease: a review on pathophysiology, clinical consequences, and treatment. Dig Surg 2007;24: 250-258. doi: 10.1159/000103655.

[25] Pluta A, Gutkowski K, Hartleb M. Coagulopathy in liver diseases. Adv Med Sci 2010;55:16-21. doi: 10.2478/v10039-010-0018-3.

[26] Boks AL, Brommer EJ, Schalm SW, Van Vliet HH. Hemostasis and fibrinolysis in severe liver failure and their relation to hemorrhage. Hepatology $1986 ; 6$ : 79-86. doi: 10.1002/hep.1840060115.

[27] Kerr R, Newsome P, Germain L, Thomson E, Dawson P, Stirling D, et al. Effects of acute liver injury on blood coagulation. J Thromb Haemost 2003 1:754-759. doi: 10.1046/j.1538-7836.2003.00194.x.

[28] Hollestelle MJ, Geertzen HG, Straatsburg IH, van Gulik TM, van Mourik JA. Factor VIII expression in liver disease. Thromb Haemost 2004;91:267-275. doi: 10.1160/TH03-05-0310.

[29] Lisman T, Porte RJ. Rebalanced hemostasis in patients with liver disease: evidence and clinical consequences. Blood 2010;116:878-885. doi: 10 . 1182/blood-2010-02-261891.

[30] Senzolo M, Burra P, Cholongitas E, Burroughs AK. New insights into the coagulopathy of liver disease and liver transplantation. World J Gastroentero 2006;12:7725-7736. doi: 10.3748/wjg.v12.i48.7725.

[31] Herrick S, Blanc-Brude O, Gray A, Laurent G. Fibrinogen. Int J Biochem Cell Biol 1999;31:741-746. doi: 10.1016/s1357-2725(99)00032-1.

[32] Green G, Thomson JM, Dymock IW, Poller L. Abnormal fibrin polymerization in liver disease. Br J Haematol 1976;34:427-439. doi: 10.1111/j.13652141.1976.th03589x.

[33] Francis JL, Armstrong DJ. Acquired dysfibrinogenaemia in liver disease. J Clin Pathol 1982;35:667-672. doi: 10.1136/jcp.35.6.667

[34] Schiødt FV, Balko J, Schilsky M, Harrison ME, Thornton A, Lee WM. Thrombopoietin in acute liver failure. Hepatology 2003;37:558-561. doi: 10 . 1053/jhep.2003.50113.

[35] Hugenholtz GC, Adelmeijer J, Meijers JC, Porte RJ, Stravitz RT, Lisman T. An unbalance between von Willebrand factor and ADAMTS13 in acute live failure: implications for hemostasis and clinical outcome. Hepatology 2013; 58:752-761. doi: 10.1002/hep.26372.

[36] Butenas S, Orfeo T, Mann KG. Tissue factor in coagulation: Which? Where? When? Arterioscler Thromb Vasc Biol 2009;29:1989-1996. doi: 10. 1161/ATVBAHA.108.177402.

[37] Grover SP, Mackman N. Tissue factor: An essential mediator of hemostasis and trigger of thrombosis. Arterioscler Thromb Vasc Biol 2018;38:709-725. doi: 10.1161/ATVBAHA.117.309846.

[38] Stravitz RT, Bowling R, Bradford RL, Key NS, Glover S, Thacker LR, et al. Role of procoagulant microparticles in mediating complications and outcome of acute liver injury/acute liver failure. Hepatology 2013;58:304-313. doi: 10 1002/hep.26307.

[39] Mancuso A, Fung K, Cox D, Mela M, Patch D, Burroughs AK. Assessment of blood coagulation in severe liver disease using thromboelastography: use of citrate storage versus native blood. Blood Coagul Fibrinolysis 2003;14:211216. doi: 10.1097/00001721-200302000-00015.

[40] Intagliata NM, Davis JPE, Caldwell SH. Coagulation pathways, hemostasis, and thrombosis in liver failure. Semin Respir Crit Care Med 2018;39:598608. doi: $10.1055 / \mathrm{s}-0038-1673658$

[41] Reikvam H, Steien E, Hauge B, Liseth $K$, Hagen KG, Størkson R, et al. Throm belastography. Transfus Apher Sci 2009;40:119-123. doi: 10.1016/j. transci.2009.01.019.

[42] Nanchal $R$, Subramanian $R$, Karvellas CJ, Hollenberg SM, Peppard W], Singbartl $\mathrm{K}$, et al. Guidelines for the management of adult acute and acute-on-chronic liver failure in the ICU: Cardiovascular, endocrine, hematologic, pulmonary, and renal considerations. Crit Care Med 2020;48:e173e191. doi: 10.1097/CCM.0000000000004192. 
Kim A. et al: Coagulopathy in acute liver failure

[43] Kang YG, Martin DJ, Marquez J, Lewis JH, Bontempo FA, Shaw BW Jr, et al. Intraoperative changes in blood coagulation and thrombelastographic monitoring in liver transplantation. Anesth Analg 1985;64:888-896. doi: 10. 1213/00000539-198509000-00008.

[44] Alamo JM, León A, Mellado P, Bernal C, Marín LM, Cepeda C, et al. Is "intraoperating room" thromboelastometry useful in liver transplantation? A casecontrol study in 303 patients. Transplant Proc 2013;45:3637-3639. doi: 10. 1016/j.transproceed.2013.11.008.

[45] Hawkins RB, Raymond SL, Hartjes T, Efron PA, Larson SD, Andreoni KA, et al. Review: The perioperative use of thromboelastography for liver transplant patients. Transplant Proc 2018;50:3552-3558. doi: 10.1016/j.transproceed.2018.07.032.

[46] Agarwal B, Wright G, Gatt A, Riddell A, Vemala V, Mallett S, et al. Evaluation of coagulation abnormalities in acute liver failure. J Hepatol 2012;57:780786. doi: 10.1016/j.jhep.2012.06.020.
[47] Lisman T, Bernal W. Management of hemostatic disorders in patients with advanced liver disease admitted to an intensive care unit. Transfus Med Rev 2017;31:245-251. doi: 10.1016/j.tmrv.2017.06.002.

[48] Davis JPE, Northup PG, Caldwell SH, Intagliata NM. Viscoelastic testing in liver disease. Ann Hepatol 2018;17:205-213. doi: 10.5604/01.3001.0010.8635.

[49] Lisman T, Bakhtiari K, Adelmeijer J, Meijers JC, Porte RJ, Stravitz RT. Intact thrombin generation and decreased fibrinolytic capacity in patients with acute liver injury or acute liver failure. J Thromb Haemost 2012;10:13121319. doi: $10.1111 /$ j.1538-7836.2012.04770.x.

[50] Habib M, Roberts LN, Patel RK, Wendon J, Bernal W, Arya R. Evidence of rebalanced coagulation in acute liver injury and acute liver failure as measured by thrombin generation. Liver Int 2014;34:672-678. doi: 10.1111/liv.12369.

[51] O'Leary JG, Greenberg CS, Patton HM, Caldwell SH. AGA clinical practice update: Coagulation in cirrhosis. Gastroenterology 2019;157:34-43.e1. doi: $10.1053 /$ j.gastro.2019.03.070. 